\title{
Chemical composition and metabolizable energy values of feedstuffs for broiler chickens ${ }^{1}$
}

\section{Eliane Aparecida da Silva ${ }^{2}$, Luiz Fernando Teixeira Albino ${ }^{3}$, Horacio Santiago Rostagno ${ }^{3}$, Valdir Ribeiro Junior ${ }^{2}$, Rodolfo Alves Vieira ${ }^{2}$, Anastácia Maria de Araújo Campos ${ }^{2}$, Rodrigo Knop Guazzi Messias ${ }^{2}$}

\footnotetext{
1 Research funded by CAPES.

2 Programa de Pós-graduação em Zootecnia-DZO/UFV.

${ }^{3}$ DZO/UFV.
}

\begin{abstract}
The objective of this study was to estimate the values of apparent metabolizable energy and apparent metabolizable energy corrected for nitrogen balance and determine the chemical composition of the following feedstuffs: babassu meal, sunflower meal, corn gluten meal, babassu starch flour, meat and bones meal, beans, millet, cookies residue, pasta residue and bread-making residue. The traditional method of excreta collection was used with broilers in the period of 14 to 24 days of age, which were distributed in a completely randomized design with eleven treatments and six replicates of six birds each. Each feedstuff replaced the reference diet at levels of 30 or $40 \%$ depending on the type of feedstuff. Chicks were housed in cages fitted with trays to collect the excreta. The apparent metabolizable energy corrected for nitrogen balance $(\mathrm{kcal} / \mathrm{kg})$ on the natural matter of feedstuffs were: babassu meal, 1,116; sunflower meal, 1,607; corn gluten meal, 3,826; babassu flour starch, 1,731; meat and bone flour, 2,524; common beans, 693; millet, 3,046; cookies residue, 3,351; pasta residue, 3,543 and bread-making residue, 3,494
\end{abstract}

Key Words: agroindustrial residues, metabolizable energy corrected, nitrogen balance

\section{Introduction}

The Brazilian poultry industry is an economic activity that plays major role in the structure of agriculture in Brazil, as a constant challenge for the technicians to achieve greater productivity with lower costs.

Despite the good knowledge of feedstuffs commonly used in poultry, it is known that there are variations in their compositions: for geographical regions, soil fertility, genetic variability of cultivars, forms of storage and processing of vegetable grains, as well as composition and method of obtaining products of animal origin are factors that influence the nutritional value of feedstuffs.

The constant evaluation of the nutritional value and energy of feedstuff to be used in feed formulation for broilers is important because it more adequately meets the nutritional needs of animals (Morata et al., 2008).

It is known that the formulation of poultry feed is mainly based on corn and soybeans; however, the availability of these grains is variable, depending on region and time of year, thus leading to variations in the costs of these raw materials, directly affecting the profitability in poultry. Therefore, an alternative to increase efficiency in animal production is the use of alternative feedstuffs, replacing the corn and soybeans in feed formulation, which might even be economical; however, it is necessary to know the nutritional values of feeds, so that rations can adequately meet the nutritional requirements of animals.

Thus, this study aimed to estimate the chemical composition, the values of apparent metabolizable energy (AME) and apparent metabolizable energy corrected by nitrogen balance (AMEn) of the following feedstuffs: babassu meal, sunflower meal, corn gluten meal, babassu starch flour, meat and bones meals, beans, millet and residues of cookies, pasta and bread-making.

\section{Material and Methods}

A biological essay was conducted in the Poultry Section of the Department of Animal Science, Universidade Federal de Viçosa, using the traditional method of total excreta collection, with growing broiler chicks during the period from 14 to 24 days old.

Chicks were housed in the floor of the first 14 days of age in a brick shed and then transferred to batteries, where the bioassay was conducted. 
Three hundred and ninety-six male broilers of the Cobb commercial strain were distributed in a completely randomized design with eleven treatments (ten feedstuffs and one reference diet) and six replicates with six chickens each.

The reference diet (Table 1) was formulated based on corn and soybean meal, with $200 \mathrm{~g}$ of crude protein $(\mathrm{CP}) / \mathrm{kg}$ diet and 3,000 kcal of metabolizable energy (ME) $/ \mathrm{kg}$ diet.

The protein feedstuffs (sunflower meal, corn gluten meal, meat and bones meal and beans) were added to the reference diet at a ratio of $30 \%$ and the energy feedstuffs (babassu meal, babassu starch flour, millet, residues from cookies, pasta and bread-making) were added to the reference diet at $40 \%$, which constituted the test diets.

The diets were fed ad libitum for a period of 10 days; the first five days for adaptation to the diets of birds and cages, and the last five days for the total collection of excreta from each experimental unit at intervals of 12 hours between each collection.

The collecting trays, covered with plastic, were placed under the floor of each experimental unit. Metal cages were equipped with trough type feeders and nipple drinkers. No light program was adopted during the experimental period.

The excreta collected were packed in plastic bags, properly identified, weighed and kept in freezer until the end of the collection period. After the collection, samples were homogenized and aliquots were taken, which were placed in a forced ventilation oven at $60{ }^{\circ} \mathrm{C}$ for pre-drying for 72 hours. Subsequently, the necessary laboratory tests were carried out (dry matter, nitrogen and gross energy) at the
Laboratory of Animal Nutrition Department of Animal Science, Universidade Federal de Viçosa, according to the methodology described by Silva \& Queiroz (2002).

At the end of the experiment, the amount of feed consumed per experimental unit during the five days of collection was determined.

Once the results of laboratory testing of feedstuffs, reference diet, test diets and excreta were obtained, values of apparent metabolizable energy (AME) and values of corrected apparent metabolizable energy (AMEn) were calculated, by means of equations proposed by Matterson et al.(1965):

$$
\begin{aligned}
& \mathrm{AME}_{\mathrm{TR}}=\text { GEcons. - GEexc. } \\
& \mathrm{DM}_{\text {cons. }} \\
& \mathrm{AME}_{\mathrm{RR}}=\text { GEcons. }- \text { GEexc. } \\
& \mathrm{DM}_{\text {cons. }} \\
& \mathrm{AME}_{\text {FEEDSTUFF }}=\mathrm{ME}_{\mathrm{RR}}+\left(\underline{\mathrm{ME}}_{\mathrm{TR}}-\mathrm{ME}_{\mathrm{RR}}\right) \\
& \mathrm{g} / \mathrm{g} \text { substitution } \\
& \mathrm{AME}_{\mathrm{nTR}}=(\text { GEcons. }- \text { GEexc. })-8,22 \times \mathrm{NB} \\
& \mathrm{DM}_{\text {cons. }} \\
& \mathrm{AME}_{\mathrm{RR}}=(\text { GEcons. }- \text { GEexc. })-8,22 \times \mathrm{NB} \\
& \mathrm{DM}_{\text {cons. }} \\
& \mathrm{AME}_{\mathrm{nFEEDSTUFF}}=\underline{\mathrm{ME}}_{\underline{n R R}}+\left(\mathrm{ME}_{\mathrm{nTR}}-\mathrm{ME}_{\mathrm{nRR}}\right) \\
& \mathrm{g} / \mathrm{g} \text { substitution } \\
& \mathrm{NB}=\mathrm{N}_{\text {cons. }}-\left(\mathrm{N}_{\text {exc }} \cdot-\mathrm{N}_{\text {exc.End. }}\right)
\end{aligned}
$$

where $\mathrm{ME}_{\mathrm{TR}}=$ apparent metabolizable energy of the test ration; $\mathrm{ME}_{\mathrm{RR}}=$ apparent metabolizable energy of the reference ration; $\mathrm{ME}_{\mathrm{FEEDSTUFF}}=$ apparent metabolizable energy of the feedstuff; $\mathrm{AME}_{\mathrm{nTR}}=$ corrected apparent metabolizable energy of the test ration; $\mathrm{AMEn}_{\mathrm{RR}}=$ corrected

Table 1 - Composition of basal diet




apparent metabolizable energy of the reference ration; $\mathrm{AME}_{\mathrm{nFEEDSTUFF}}=$ corrected apparent metabolizable energy of the feedstuff; $\mathrm{GE}_{\text {cons. }}=$ gross energy consumed; $\mathrm{GE}_{\text {exc. }}=$ gross energy excreted; $\mathrm{NB}=$ nitrogen balance; $\mathrm{N}_{\text {cons }}=$ nitrogen consumed; $\mathrm{N}_{\text {exc }}$. = nitrogen excreted; $\mathrm{N}_{\text {exc.End }}=$ endogenous nitrogen excreted; $\mathrm{DM}_{\text {cons. }}=$ dry matter consumed.

The average temperature in the metabolism room during the trial was recorded every day at 08:00. Dry bulb thermometers were placed at different locations inside the room of metabolism. The average maximum and minimum temperatures recorded during the experimental period were 25.5 and $16.6^{\circ} \mathrm{C}$, respectively.

\section{Results and Discussion}

There was variation in the chemical composition of feedstuffs studied (Tables 2 and 3 ), which is normal, especially when it comes to feedstuff of various origins, growing conditions, soil, climate and cultivar (Albino \& Silva, 1996).

For sunflower meal, in the present study, the value of crude protein was higher than the values described by Tavernari et al. (2010): $280.9 \mathrm{~g} / \mathrm{kg}$ and Stringhini et al. (2000):
$273.6 \mathrm{~g} / \mathrm{kg}$, but it was lower than the value described by Valadares Filho et al. (2006): $353.3 \mathrm{~g} / \mathrm{kg}$. The babassu meal presented crude protein value lower than the obtained by Cavalcante et al. (2005). The bread-making residues evaluated presented crude protein value 36\% higher than those cited by Valadares Filho et al. (2006). Babassu starch flour presented crude protein value 5\% lower than that found by Silva (2008), which was $20.1 \mathrm{~g} \mathrm{~kg}$.

According to Osborn (1988), legume seeds have high protein content, and the protein content varies between 160 and $330 \mathrm{~g} / \mathrm{kg}$ for various types of beans. The bean evaluated in this study presented higher crude protein value for all varieties analyzed by Pires et al. (2005).

Wide variation in the chemical composition of meat and bones can be found, probably due to differences in the proportions of shares disposed at the slaughterhouse and processing methods. Satorelli (1998) evaluated the chemical composition of the top ten meat and bones of Minas Gerais and observed values of crude protein varying from 349.9 to $563.0 \mathrm{~g} / \mathrm{kg}$. In several studies it is possible to observe great variation in crude protein content of meat and bone (Brum et al., 2002; Tucci et al., 2003; Nunes et al., 2005, 2006). In addition, Nunes et al. (2005) reported that crude protein

Table 2 - Chemical composition of feedstuffs expressed in natural matter ${ }^{1}$

\begin{tabular}{|c|c|c|c|c|c|c|}
\hline Feedstuff & $\begin{array}{c}\mathrm{DM} \\
(\mathrm{g} / \mathrm{kg})\end{array}$ & $\begin{array}{c}\mathrm{CP} \\
(\mathrm{g} / \mathrm{kg})\end{array}$ & $\begin{array}{c}\mathrm{EE} \\
(\mathrm{g} / \mathrm{kg})\end{array}$ & $\begin{array}{c}\text { MM } \\
(\mathrm{g} / \mathrm{kg})\end{array}$ & $\begin{array}{c}\mathrm{Ca} \\
(\mathrm{g} / \mathrm{kg})\end{array}$ & $\begin{array}{c}P \\
(\mathrm{~g} / \mathrm{kg})\end{array}$ \\
\hline Babassu starch flour & 862.7 & 19.1 & 2.9 & 25.0 & 1.0 & 1.0 \\
\hline Babassu meal & 937.5 & 194.9 & 21.5 & 40.6 & 1.2 & 12.3 \\
\hline Cookies, residue & 931.9 & 73.5 & 43.4 & 6.0 & 0.3 & 1.7 \\
\hline Meat and bones meal $(51 \%)$ & 922.6 & 509.5 & 113.8 & 246.5 & 84.7 & 22.7 \\
\hline Beans & 893.8 & 263.8 & 5.9 & 40.8 & 1.5 & 6.7 \\
\hline Sunflower meal & 883.4 & 316.5 & 5.4 & 53.5 & 3.4 & 13.4 \\
\hline Pasta residue & 884.7 & 126.6 & 0.9 & 6.5 & 0.8 & 2.7 \\
\hline Millet & 884.1 & 92.2 & 23.5 & 15.1 & 0.4 & 5.3 \\
\hline Corn gluten meal $(60 \%)$ & 928.8 & 682.8 & 12.7 & 16.6 & 0.3 & 8.4 \\
\hline Bread-making residue & 853.9 & 151.5 & 15.7 & 25.2 & 1.9 & 3.3 \\
\hline
\end{tabular}

DM - dry matter; CP - crude protein; EE - ether extract; MM - mineral matter; Ca - calcium; P - phosphorus.

1 Analyses conducted at the Laboratory of Animal Nutrition of the Department of Animal Science, Universidade Federal de Viçosa.

Table 3 - Chemical composition and crude energy values of feedstuffs, expressed in natural material ${ }^{1}$

\begin{tabular}{|c|c|c|c|c|c|}
\hline Feedstuffs & $\begin{array}{c}\mathrm{DM} \\
(\mathrm{g} / \mathrm{kg})\end{array}$ & $\begin{array}{c}\mathrm{CF} \\
(\mathrm{g} / \mathrm{kg})\end{array}$ & $\begin{array}{l}\text { NDF } \\
(\mathrm{g} / \mathrm{kg})\end{array}$ & $\begin{array}{c}\text { ADF } \\
(\mathrm{g} / \mathrm{kg})\end{array}$ & $\begin{array}{c}\mathrm{GE} \\
(\mathrm{kcal} / \mathrm{kg})\end{array}$ \\
\hline Babassu starch flour & 862.7 & 96.9 & 370.9 & 150.9 & 3687 \\
\hline Babassu meal & 937.5 & 475.2 & 632.1 & 369.3 & 4553 \\
\hline Cookies residue & 931.9 & 16.0 & 22.2 & 10.3 & 4139 \\
\hline Meat and bones meal $(51 \%)$ & 922.6 & n.e. & n.e. & n.e. & 4165 \\
\hline Beans & 893.8 & 139.2 & 353.8 & 77.0 & 3978 \\
\hline Sunflower meal & 883.4 & 290.9 & 418.6 & 24.2 & 4324 \\
\hline Pasta residue & 884.7 & 17.4 & 8.2 & 6.6 & 3931 \\
\hline Millet & 884.1 & 39.3 & 267.2 & 38.1 & 3912 \\
\hline Corn gluten meal (60\%) & 928.8 & 11.2 & 352.1 & 307.9 & 5468 \\
\hline Bread-making residue & 853.9 & 10.2 & 61.3 & 7.9 & 3926 \\
\hline
\end{tabular}

DM - dry matter; CF - crude fiber; NDF - neutral detergent fiber; ADF - acid detergent fiber; GE - gross energy; n.e. - not evaluated.

${ }^{1}$ Analyses conducted at the Laboratory of Animal Nutrition Department of Animal Science, Universidade Federal de Viçosa. 
content of meat and bone is inversely proportional to the percentage of mineral matter, which is directly related to the proportion of bone and cartilage tissue contained in the flour. According to the various classifications given to meat and bones on the Brazilian Charts (Rostagno et al., 2005 ) with respect to crude protein content, which varies from 350 to $600 \mathrm{~g} / \mathrm{kg}$ in natural matter; this flour evaluated is in the group of meat and bone meal of $510.0 \mathrm{~g} / \mathrm{kg}$. In addition, the meat and bones studied presented values of crude protein 5\% lower than that obtained by Nery (2005).

It can be observed that the value of sunflower meal ether extract (EE) was lower than those found in the literature: Valadares Filho et al. (2006), Stringhini et al. (2000), Mantovani et al. (2000) and Tavernari et al. (2010).

The babassu meal presented value of ether extract higher than that determined by Valadares Filho et al. (2006): $18.2 \mathrm{~g} / \mathrm{kg}$. However, it was lower than that found by Albino (1980), $74.9 \mathrm{~g} / \mathrm{kg}$ and Silva (2006), $58.7 \mathrm{~g} / \mathrm{kg}$.

The babassu flour starch showed the lowest value of ether extract obtained in relation to the other feedstuffs evaluated. In addition, it presented a value lower than that obtained by Silva (2008), of $18.8 \mathrm{~g} / \mathrm{kg}$.

Comparing the results obtained for the ether extract of corn gluten meal, it can be observed that it was lower than the value obtained by Rodrigues et al. (2001). Nevertheless, it was higher than the value determined by Brumano et al. (2006). Comparing the value of ether extract of millet evaluated in this study, we see that the value obtained by Gomes et al. (2008) was higher, and the results obtained by Pinheiro et al. (2003) and Nagata et al. (2004) were also higher.

Babassu meal presented a calcium $(\mathrm{Ca})$ value lower than that obtained by Cavalcante et al. (2005): $6.5 \mathrm{~g} / \mathrm{kg}$ based on natural matter, but, the value of phosphorus $(\mathrm{P})$ was higher than that described by the same authors: $8.2 \mathrm{~g} / \mathrm{kg}$; also based on natural materials. In addition, both the content of calcium and phosphorus in the babassu meal were higher by $33 \%$ and $64 \%$ respectively, than those described by Valadares Filho (2000).

The cookie residue studied showed higher calcium value at $66 \%$ of the value found by Nunes et al. (2001). With respect to the phosphorus content, the cookie residue presented value $18 \%$ higher than that mentioned by Rostagno et al. (2005).

For the corn gluten meal evaluated, the amount of calcium was lower than the amount shown by the NRC (1998), although it was higher than the value obtained by Brumano et al. (2006). The amount of phosphorus found in this study for the corn gluten was higher than both the value described by Rodrigues et al. (2001), and that described by Rostagno et al. (2005).
The meat and bones evaluated in this study had value higher than that of calcium determined by Nery (2005), but lower than the value found by Nunes et al. (2005). In addition, meat and bones showed a low content of phosphorus in relation to the value described by Vieites (1999) and Rostagno et al. (2005). These variations occurring in the composition and energy value of ingredients in processed products are more evident, since there is no standardization in the process of production (Tucci et al., 2003).

The result obtained for the calcium content of millet was lower than the value obtained by Bastos et al. (2004): $0.5 \mathrm{~g} / \mathrm{kg}$, but was higher than the value described by Rostagno et al. (2005): $0.3 \mathrm{~g} / \mathrm{kg}$. With respect to phosphorus content, the results obtained by Rodrigues et al. (2001) for the two varieties evaluated, $2.6 \mathrm{~g} / \mathrm{kg}$ and $1.8 \mathrm{~g} / \mathrm{kg}$, were below the result obtained in this study and also lower than the result obtained by Gomes et al. (2008): $3.1 \mathrm{~g} / \mathrm{kg}$.

Both values of neutral detergent fiber (NDF) and of acid detergent fiber (ADF) of sunflower meal were lower than those found by Santos et al. (2005). Values of neutral and acid detergent fiber were, respectively, higher and lower than those cited by Valadares Filho et al. (2006), with NDF equal to $389.0 \mathrm{~g} / \mathrm{kg}$ and ADF equal to $320.5 \mathrm{~g} / \mathrm{kg}$ as fed.

The values of NDF and ADF babassu meal were the highest values obtained in relation to other feedstuffs assessed, since this is residue from the extraction of babassu coconut oil, consisting mainly of fibrous parts of the fruit, the mesocarp, epicarp and endocarp (layers that cover the almonds) and the almonds. The NDF value found in this study was higher than the value found by Cavalcante et al. (2005), while the value of FDA was similar to the value found by Cavalcante et al. (2005). However, the value of NDF was lower and the value of ADF was higher with respect to values determined Vieira et al. (2007).

For the corn gluten meal evaluated in this study, both the values of NDF and ADF were higher than those determined by Rostagno et al. (2005), NDF $=63.9 \mathrm{~g} / \mathrm{kg}$ and $\mathrm{ADF}=86.3 \mathrm{~g} / \mathrm{kg}$; by Brumano et al. (2006), $\mathrm{NDF}=80.5 \mathrm{~g} / \mathrm{kg}$ and $\mathrm{ADF}=33.1 \mathrm{~g} / \mathrm{kg}$; by Rodrigues et al. (2001), $\mathrm{NDF}=$ $33.2 \mathrm{~g} / \mathrm{kg}$ and $\mathrm{ADF}=176.8 \mathrm{~g} / \mathrm{kg}$ and by Lima (2008), $\mathrm{NDF}=$ $235.7 \mathrm{~g} / \mathrm{kg}$ and $\mathrm{ADF}=118.3 \mathrm{~g} / \mathrm{kg}$. These differences in values of NDF and ADF are probably due to the enzyme amylase used during the NDF procedure analysis performed in this research, since many tests were conducted using the same enzyme and the results were very similar. The enzyme amylase acts on starch degradation in the feedstuff, preventing, so, subsequent formation of resistant starch when the sample is heated in the presence of water, so if the enzyme amylase does not act effectively in the 
degradation of starch, the formation of resistant starch will then occur, thus helping to overestimate the values of both the NDF and ADF, since this resistant starch is not degraded in the later stages of use of the enzyme amylase during the procedure of the analysis of NDF and ADF. Besides, due to the fact that corn gluten meal has high protein content, this may also contribute to overestimate the values of both NDF and ADF, since the nitrogen compounds are not completely removed during the procedure of analysis NDF and ADF, so these compounds are considered contaminants of NDF and ADF.

Millet presented higher values of NDF and ADF than those obtained by Nagata et al. (2004):NDF equal to $162.6 \mathrm{~g} / \mathrm{kg}$ and ADF equal to $51.5 \mathrm{~g} / \mathrm{kg}$. On the contrary, Pinheiro et al. (2003) found lower values of NDF: $207.5 \mathrm{~g} / \mathrm{kg}$; and higher values of ADF: $117.1 \mathrm{~g} / \mathrm{kg}$, with respect to the values found for millet in the present research.

Comparing the value of gross energy obtained for sunflower meal evaluated in this study with the value described by Tavernari et al. (2010), we can observe that the value was higher than the feedstuff evaluated in the present study, but when comparing with Mantovani et al. (2000) the values obtained here were superior.

It could be observed that the babassu meal presented great energy content; however, the major limitation on its use is primarily due to its high content of fiber.

Meat and bones presented gross energy value lower than those found by Vieites (1999) and Nery (2005); however, it showed a value higher than that mentioned by Rostagno et al. (2005). These differences in chemical composition and energy of feedstuff of animal origin are expected and emphasize the importance of updating these values for being used to calculate more precise diets that meet the requirements of the animals properly.

The gross energy value of millet evaluated in this study was lower than the values found for the two varieties evaluated by Rodrigues et al. (2001), as well as the values found for the varieties evaluated by Nagata et al. (2004).

The values of apparent metabolizable energy (AME) of the feedstuffs evaluated (Table 4) were higher than the corrected apparent metabolizable energy (AMEn) except for the pasta residue. According to Nery (2005), this is a normal characteristic when the metabolizable energy values are determined on growing birds, because at this stage retention of nitrogen is greater than deposition of protein tissue; this is accentuated when making corrections for metabolic and endogenous losses.

According to Nunes (2003), it is necessary to correct the estimated values of energy for nitrogen balance since, during the metabolism trial, it is impossible to ensure that all birds present the same growth rate.

The AMEn value of sunflower meal was lower than the value found by Tavernari et al. (2010), but was higher than the values reported by Mantovani et al. (2000) and Stringhini et al. (2000). According to Tavernari et al. (2010), high levels of fiber sunflower meal are directly related to its low metabolizable energy and nutrient utilization by monogastric animals, which, in turn, leads to worsening of the productive performance.

Babassu meal presented low AMEn value, since it is a feedstuff rich in fiber, which implies an incomplete degradation of feedstuff in the digestive system of birds, because the fiber increases the transit time of feed through the gastrointestinal tract.

The AMEn value for bread-making residue was lower than the values reported by the NRC (1994) and the Janssen (1989).

With respect to the AMEn values found for the residues of pasta and cookie evaluated, these were higher and lower than the values cited by Rostagno et al. (2005), respectively. However, the AMEn values of residues of pasta and cookies evaluated were lower by $10 \%$ and $23 \%$ respectively, compared with the values obtained by Nunes et al. (2001).

Table 4 - Apparent metabolizable energy (AME), corrected apparent metabolizable energy (AMEn) and coefficients of apparent metabolization (CAM) and corrected apparent metabolization (CAMn)

\begin{tabular}{lcccc}
\hline Feedstuffs & $\begin{array}{c}\text { DM } \\
(\mathrm{g} / \mathrm{kg})\end{array}$ & $\begin{array}{c}\text { AME } \\
(\mathrm{kcal} / \mathrm{kg})\end{array}$ & $\begin{array}{c}\text { AMEn } \\
(\mathrm{kcal} / \mathrm{kg})\end{array}$ & $\begin{array}{c}\text { CAM } \\
(\mathrm{kcal} / \mathrm{kg})\end{array}$ \\
\hline Babassu starch flour & 862.7 & 1,751 & 1,731 & 0.47 \\
Babassu meal & 937.5 & 1,337 & 1,116 & 0.29 \\
Cookies residue & 931.9 & 3,380 & 3,351 & 0.47 \\
Meat and bones meal (51\%) & 922.6 & 2,686 & 2,524 & 0.24 \\
Beans & 893.8 & 702 & 693 & 0.84 \\
Sunflower meal & 883.4 & 1,781 & 1,607 & 0.18 \\
Pasta residue & 884.7 & 3,541 & 3,543 & 0.41 \\
Millet & 884.1 & 3,065 & 3,046 & 0.90 \\
Corn gluten meal (60\%) & 928.8 & 3,939 & 3,826 & 0.78 \\
Bread-making residue & 853.9 & 3,549 & 3,494 & 0.72 \\
\hline
\end{tabular}

DM - dry matter. 
For the corn gluten meal evaluated in this study, the AMEn value was higher than that described by Rostagno et al. (2005) and Brumano et al. (2006), but lower than the AMEn value determined to 22- to 26-day old chicks by Rodrigues et al. (2001).

The meat and bones evaluated in this study had AMEn value below that mentioned by Rostagno et al. (2005), although they presented values higher than those obtained by Nery (2005) and by Vieites (1999), who evaluated six meat and bones meals.

The result obtained for AMEn of millet evaluated in this study was greater than the values found for two different varieties, determined by total fecal collection described by Nagata et al. (2004), and by Gomes et al. (2008).

As for corrected apparent metabolizability coefficient (CAMn) obtained in this study, beans had a lower CAMn value compared with the other feedstuffs evaluated, which may be explained by the presence of antinutritional factors; and, according to Bonett et al. (2007), there are several substances in the beans that act as antinutritional factors, and may highlight the tannins, phytates, protease inhibitors and lectins, which may act by inhibiting the action of digestive enzymes, complexing with nutrients (carbohydrates, amino acids and minerals) and affecting the absorption and utilization of these birds. These antinutritional factors most often are inhibited by thermal processes, since they are considered labile, and the beans used in this experiment did not suffer any kind of thermal process.

The CAMn value for sunflower meal was lower than the value obtained by Tavernari et al. (2010): 0.447; however, it was higher than the value given by Mantovani et al. (2000): 0.369.

Babassu meal and sunflower meal also presented low efficiency of energy metabolization, possibly due to the high amount of fiber contained in these feedstuffs. The greater presence of fiber in feedstuff may lead to an increase in transit time through its gastrointestinal tract, causing a decrease in the digestibility of other nutrients like fat and protein. According to D'Agostini et al. (2004), birds present low energy metabolization of the feedstuffs high in fiber content.

\section{Conclusions}

The values of apparent metabolizable energy corrected by nitrogen balance based on natural matter determined in broilers from 18 to 24 days old are: babassu meal $1,116 \mathrm{kcal} / \mathrm{kg}$; sunflower meal - $1,607 \mathrm{kcal} / \mathrm{kg}$; corn gluten meal - 3,826 kcal $/ \mathrm{kg}$; babassu starch flour - $1,731 \mathrm{kcal} / \mathrm{kg}$; meat and bones - 2,524 kcal $/ \mathrm{kg}$; beans - $693 \mathrm{kcal} / \mathrm{kg}$; millet $3,046 \mathrm{kcal} / \mathrm{kg}$; cookies residue - 3,351 kcal/kg; pasta residue - 3,543 $\mathrm{kcal} / \mathrm{kg}$; and bread-making residue $3,494 \mathrm{kcal} / \mathrm{kg}$.

\section{References}

ALBINO, L.F.T. Determinação de valores de energia metabolizável e triptofano de alguns alimentos para aves em diferentes idades. 1980. 55f. Dissertação (Mestrado em Zootecnia) - Universidade Federal de Viçosa, Viçosa, MG.

ALBINO, L.F.T.; SILVA, M.A. Valores nutritivos de alimentos para aves e suínos determinados no Brasil. In: SIMPÓSIO INTERNACIONAL SOBRE EXIGÊNCIAS NUTRICIONAIS DE AVES E SUÍnOS, 1996, Viçosa, MG. Anais... Viçosa, MG: Universidade Federal de Viçosa, 1996. p.303-318.

BASTOS, A.O.; MOREIRA, I.; MURAKAMI, A.E.M. et al. Utilização do milheto (Penisetum glaucum (L.) Brown) grão na alimentação de suínos na fase inicial (15-30 kg de peso vivo). Revista Ciência Rural, v.34, n.6, p.1915-1919, 2004.

BONETT, L.P.; BAUMGARTHER, M.S.T.; KLEIN, A.C. et al. Compostos nutricionais e fatores antinutricionais do feijão comum (Phaseolus vulgares L.). Arquivos de Ciência da Saúde, v.11, n.3, p.235-2462007.

BRUMANO, G.; GOMES, P.C.; ALBINO, L.F.T. et al. Composição química e valores de energia metabolizável de alimentos protéicos para frangos de corte em diferentes idades. Revista Brasileira de Zootecnia, v.35, n.6, p.2297-2302, 2006.

BRUM, P.A.; AVILA, P.A.R.; MAIER, V.S. et al. Valores de energia metabolizável da farinha de carne e ossos e farinha de vísceras determinados com diferentes níveis de substituição para frangos de corte. Revista Brasileira de Agrociência, v.8, n.1, p.51-55, 2002.

CAVALCANTE, R.R.; FIGUEREDO A.V.; CARVALHO, M.A.M. et al. Digestibilidade aparente de nutrientes de rações balanceadas com alimentos alternativos para cutias (Dasyprocta prymnolopha) em crescimento. Revista Ciência Animal Brasileira, v.6 n.3, p.163-171, 2005.

D'AGOSTINI, P.; GOMES, P.C.; ALBINO, L.F.T. Valores de composição química e energética de alguns alimentos para aves Revista Brasileira de Zootecnia, v.33, n.1, p.128-134, 2004 GOMES, P.C.; RODRIGUES, M.P.; ALBINO, L.F.T. et al. Determinação da composição química e energética do milheto e sua utilização em rações para frangos de corte de 1 a 21 dias de idade. Revista Brasileira de Zootecnia, v.37, n.9, p.1617-1621, 2008.

JANSSEN, W.M.M.A. European table of energy values for poultry feedstuffs. 3.ed. Beekbergen, 1989. 84p. (Spelderhol Center for Poultry Research and Information Services).

LIMA, R.B. Avaliação nutricional de derivados da moagem úmida do milho para frangos de corte industrial. Recife: Universidade Federal Rural de Pernambuco, 2008. $70 \mathrm{f}$ Dissertação (Mestrado em Zootecnia) - Universidade Federal Rural de Pernambuco, Recife.

MANTOVANI, C.; FURLAN, A.C.; MURAKAMI, A.E. et al. Composição química e valor energético do farelo e da semente de girassol para frangos de corte. Acta Scientarium, v.22, n.3, p.745-749, 2000.

MATTERSON, L.D.; POTTER, L.M.; STUTZ, M.W. et al. 1965 The metabolizable energy of feed ingredients for chickens. Agricultural Experiment Station Research Report, v.11, p. 11,1965

MORATA, R.L.; TAVERNARI, F.C.; VIEIRA, R.A. et al. Valores nutricionais de alguns alimentos para frangos de corte. Suplemento Revista Brasileira de Ciência Avícola Prêmio Lamas, v. 10, p.53, 2008. 
NAGATA, A.K.; RODRIGUES, P.B.; FREITAS, R.T.F. et al. Energia metabolizável de alguns alimentos energéticos para frangos de corte determinada por ensaios metabólicos e por equações de predição. Ciência e Agrotecnologia, v.28, n.3, p.668-677, 2004

NATIONAL RESEARCH COUNCIL - NRC. Nutrient requirements of poultry. 9.ed. Washington, D.C.: National Academy of Sciences, 1994. 155p.

NATIONAL RESEARCH COUNCIL - NRC. Nutrient requeriments of swine. 10.ed. Washington, D.C.: National Academy Press, 1998. $189 \mathrm{p}$

NERY, L.R. Valores de energia metabolizável e aminoácidos digestíveis de alguns alimentos para aves. 2005. $87 \mathrm{f}$. Dissertação (Mestrado em Zootecnia) - Universidade Federal de Viçosa, Viçosa, MG.

NUNES, R.V.; ROSTAGNO, H.S.; ALBINO, L.F.T. et al. Composição bromatológica, energia metabolizável e equações de predição da energia do grão e de subprodutos do trigo para pintos de corte. Revista Brasileira de Zootecnia, v.30, n.3, p.785-793, 2001

NUNES, R.V. Digestibilidade de nutrientes e valores energéticos de alguns alimentos para aves. 2003. $113 \mathrm{f}$. Tese (Doutorado em Zootecnia) - Universidade Federal de Viçosa, Viçosa, MG.

NUNES, R.V.; POZZA, P.C.; NUNES, C.G.V. et al. Valores energéticos de subprodutos de origem animal para aves. Revista Brasileira de Zootecnia, v.34, n.4, p.1217-224, 2005

NUNES, R.V.; ROSTAGNO, H.S.; GOMES, P.C. et al. Valores energéticos de diferentes alimentos de origem animal para aves. Revista Brasileira de Zootecnia, v.35, n.4, p.1752-757, 2006 .

OSBORN, T.C. Genetic control of beans seed protein. Critical Reviews Plant Sciences, v.7, p.93-116, 1988.

PINHEIRO, M.S.M.; FIALHO, E.T.; LIMA, J.A.F. et al. Milheto moído em substituição ao milho em rações para suínos em crescimento: digestibilidade e desempenho. Revista Brasileira de Milho e Sorgo, v.2, n.2, p.99-109, 2003

PIRES, C.V.; OLIVEIRA, M.G.A.; CRUZ, G.A.D.R. et al. Composição química de diferentes cultivares de feijão (Phaseolus vulgaris L.). Alimentos e Nutrição, v.16, n.2, p.157-162, 2005

RODRIGUES, P.B.; ROSTAGNO, H.S.; ALBINO, L.F.T. et al. Valores energéticos do milheto, do milho e subprodutos do milho, determinados com frangos de corte e galos adultos. Revista Brasileira de Zootecnia, v.30, n.6, p.1767-1778, 2001.

ROSTAGNO, H.S.; ALBINO, L.F.T; DONZELE, J.L. et al. Tabelas brasileiras para aves e suínos: composição de alimentos e exigências nutricionais. Viçosa, MG: Universidade Federal de Viçosa, 2005. 186p.

SANTOS, Z.A.S.; FREITAS, R.T.F.; FIALHO, E.T. et al. Valor nutricional de alimentos para suínos determinados na Universidade Federal de Lavras. Revista Ciência e Agrotecnologia, v.29, n.1, p.232-237, 2005.

SATORELLI, S.A.A. Uso de farinha de carne e ossos em rações de frangos de corte. 1998. Dissertação (Mestrado em Zootecnia) - Universidade Federal de Lavras, Lavras.

SILVA, D.J.; QUEIROZ, A.C. Análise de alimentos (métodos químicos e biológicos). 3.ed. Viçosa, MG: UFV, 2002. 235p.

SILVA, T.C.P. Substituição do farelo de trigo pela torta de babaçu na alimentação de vacas mestiças em lactação. 2006. 30f. Dissertação (Mestrado em Zootecnia) - Universidade Federal Rural de Pernambuco, Recife.

SILVA, N.R. Desempenho produtivo de bovinos de corte alimentados com dietas contendo diferentes níveis de farinha amilácea de babaçu. 2008. 78f. Dissertação (Mestrado em Zootecnia) - Universidade Federal do Tocantins, Tocantis.

STRINGHINI, J.H.; CAFÉ, M.B.; FERNANDES, C.M. et al. Avaliação do valor nutritivo do farelo de girassol para aves. Revista Ciência Animal Brasileira, v.1, n.2, p.123-126, 2000.

TAVERNARI, F.C.; MORATA, R.L.; RIBEIRO JÚNIOR, V. et al Avaliação nutricional e energética do farelo de girassol para aves. Arquivo Brasileiro de Medicina Veterinária e Zootecnia, v.62, n.1, p.172-177, 2010 .

TUCCI, F.M.; LAURENTIZ, A.C.; SANTOS, E.A. Determinação da composição química e dos valores energéticos de alguns alimentos para aves. Acta Scientarum Animal Sciences, v. 25, n. 1, p. $85-89,2003$

VALADARES FILHO, S.C. Nutrição, avaliação de alimentos e tabelas de composição de alimentos para bovinos. In: REUNIÃO ANUAL DA SOCIEDADE BRASILEIRA DE ZOOTECNIA, 37. 2000, Viçosa, MG. Anais... Viçosa, MG: Sociedade Brasileira de Zootecnia, 2000. p.267-330.

VALADARES FILHO, S.C.; MAGALHÃES, K.A.; ROCHA JÚNIOR, V.R. et al. Tabelas brasileiras de composição de alimentos para bovinos. 2.ed. Viçosa, MG: DZO-UFV, 2006. 329p.

VIEITES, F.M. Valores energéticos e de aminoácidos digestíveis de farinhas de carne e ossos para aves. 1999 75 f. Dissertação (Mestrado em Zootencia) - Universidade Federal de Viçosa, Viçosa, MG.

VIEIRA, R.O.; RODRIGUES, P.B.; FREITAS, R.T.F. et al Composição química e energia metabolizável de híbridos de milho para frangos de corte. Revista Brasileira de Zootecnia, v.36, n. 4, p.832-838, 2007. 